\title{
Day Times Gram Per Milliliter Per Kilogram
}

National Cancer Institute

\section{Source}

National Cancer Institute. Day Times Gram Per Milliliter Per Kilogram. NCI Thesaurus.

Code C112247.

Days times grams per milliliter, divided by kilograms. 